\title{
Understanding Forest Fire Management in Indonesia from a Global Perspective
}

\author{
Indra Agus Riyanto ${ }^{1, *}$, Ahmad Cahyadi ${ }^{2}$, Faricha Kurniadhini ${ }^{3}$, Hafidz Bachtiar ${ }^{2}$, Dwiki Apriyana ${ }^{2}$, and Brian \\ Kannardi Aji Caraka² \\ ${ }^{1}$ Lentera Geosains, Jl Tongkol V, RT 08, No. 18, Yogyakarta 55581, Indonesia \\ ${ }^{2}$ Department of Environmental Geography, Faculty of Geography, Universitas Gadjah Mada, Yogyakarta 55281, Indonesia \\ ${ }^{3}$ Department of Architecture and Planning, Faculty of Engineering, Universitas Gadjah Mada, Yogyakarta 55281, Indonesia \\ ${ }^{*}$ Corresponding author: indra.agus.r@gmail.com
}

\author{
KEYWORDS \\ Forest fire \\ Disaster management \\ Disaster regulation
}

\begin{abstract}
Forest fires are one of the global issues that attract worldwide attention. Russia, Brazil, Canada, the United States, and Indonesia are among the countries with the largest forest cover and long records of massive forest fires. Forest fire management is, therefore, critical to decreasing the severity level of these fires. Current conditions indicate that, compared with the four other countries, Indonesia has significantly reduced forest fires within the past five years. Consequently, adopting a global perspective to study the characteristics of forest fire disaster management has become necessary. For each management parameter, this research employed a literature review and descriptive analysis. The results showed that Indonesia had an advantage in the field of legal regulation. Indonesia tends to change its regulations within a short span of time, resulting in the number of forest fire incidents decreasing significantly compared with Russia, Brazil, Canada, and the United States. However, the country still has several weaknesses, namely in emergency responses, forest fire monitoring technology, and inter-institutional integration in forest fire disaster management.
\end{abstract}

(c) The Author(s) 2020. This article is distributed under a Creative Commons Attribution-ShareAlike 4.0 International license.

\section{INTRODUCTION}

Forests, through their essential functions, are inextricably linked to human society and the global economy ([WRI] World Resources Institute c2020). Forests are also vital natural resources for environmental preservation, economic productivity, and water and soil conservation (Gebrehiwot et al. 2014). Sustainably managed forests produce essential goods and services and, accordingly, play a crucial role in sustainable development (FAO 2015). In addition to food for human needs, forests provide habitats for pollen that determines the continuity of agriculture reproduction (CIFOR c2020). However, in their utilization, conflicts between the industrial sector and the environment are inevitably ubiquitous. For example, forests are often cleared for industrial purposes (PPI Dunia 2017). Industrial needs to enhance economic growth have led to the depletion of natural resources like forests, which eventually imbalances economic and ecological sustainability (Salghuna et al. 2018). Furthermore, depletion of natural resources is linked to population growth, which puts pressure on biological systems (Pringadi 2004).

In Indonesia, forests are referred to as the nation's 'lungs' because they provide oxygen for the human respiratory system. Unfortunately, in some Indonesian islands, the forests have been converted into unsustainable oil palm plantations. According to Global Forest Watch, the deforestation rate from 1990 to 2015 in this country was 1.1\% per year. The most common form of deforestation in Indonesia is land clearing by burning the forest, which results in forest fires. Slash-and-burn practices are not the only cause of forest fires, however. For example, drought is also known to cause forest fires in Indonesia and some other countries (Tacconi 2003). Figure 1 shows the number of forest fires in five countries, namely Russia, Brazil, Canada, the United States, and Indonesia.

According to Figure 1, the number of forest fires in all countries dropped between 2012 and 2018. Russia showed the sharpest decline from 500,000 incidents in 2012 to below 100,000 in 2018. The La Nina that occurred in 2013 influenced the decreasing trend of forest fires in all countries except Canada, while the El Nino that occurred in 20142015 influenced the increasing trend of forest fires in Indonesia, Brazil, and the United States. Although the trend fluctuates, all countries mentioned in Figure 1 have a lowest occurrence of forest fires in 2018 that is lower than that in

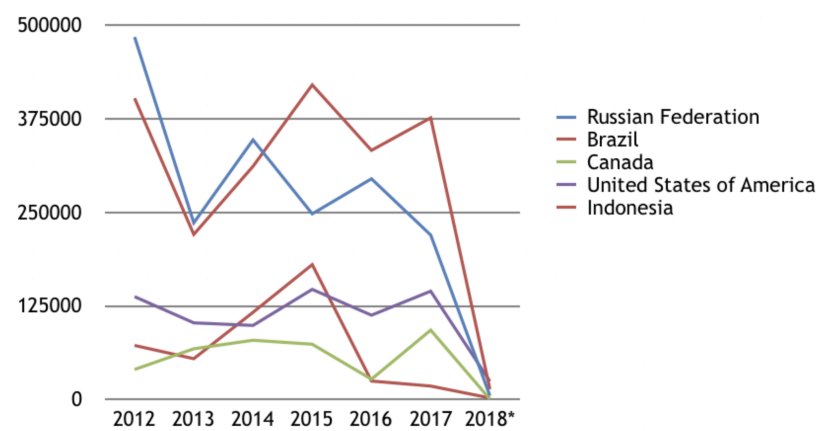

FIGURE 1. The number of forest fires in Russia, Brazil, Canada, the United States, and Indonesia (WRI c2020). 
2012, and this may depict the capacity of disaster management in these countries.

Forest fires not only lead to loss of human life but block roads, railway lines, and electricity, cut mobile- and landlines, destroy homes and industries, and imbalance people's way of life (Rábade and Aragoneses 2008; Hirschberger 2016). Forest fire mitigation strategies in provincial, regional, and municipal agencies are important by distinguishing social structure of what constitutes ecologically sustainable forest management (Goemans and Ballamingie 2013). One way to improve forest management and community safety is by evaluating regulations on disaster management in one country and comparing them with those of other countries.

\section{MATERIALS AND METHODS}

The materials used in this research were from the governmental institutions of five countries: Indonesia, Brazil, the United States, Russia, and Canada. They consisted of legal and regulatory documents relevant to disaster management (Table 1). The documents were used to identify each country's efforts to deal with forest fires according to the disaster management cycle, which comprises response, rehabilitation, reconstruction, prevention, mitigation, preparedness, and institution.

A literature review was used to compare forest fire management in the five countries . Each parameter was defined and described in detail according to the disaster management cycle introduced by the United Nations Office for Disaster Risk Reduction (UNISDR); this cycle starts with response, rehabilitation, reconstruction, prevention, mitigation, preparedness, and institution (UNISDR 2017). UNISDR offers an international standard that all UN member countries have agreed on and established. To identify the difference between the disaster management of the five selected countries, the researchers employed a descriptivequalitative approach to analyze website articles, law and regulations, official reports, and journal articles. Some references that used this approach are the research by Beuchelt and Virchow (2012), which compared the concept of food sovereignty, and that by Riyanto et al. (2019), which compared disaster information based on web usability.

\section{RESULTS AND DISCUSSION}

This research highlights the importance of comparing disaster management between countries to fully understand how Indonesia has been dealing with forest fires. The com-

TABLE 1. List of documents sources.

\begin{tabular}{|c|c|}
\hline Country & Legal and regulation documents \\
\hline Indonesia & $\begin{array}{l}\text { Law No. } 32 \text { of } 2009 \text { (Undang-Undang No } 32 \text { Tahun } \\
\text { 2009) }\end{array}$ \\
\hline Brazil & $\begin{array}{l}\text { National Policy of Civil Protection and Defense } n \text {. } \\
12,608 \text { of } 2012\end{array}$ \\
\hline United States & $\begin{array}{l}\text { Forest Management Act } 1976 \text { and } 16 \text { U.S. Code } \\
\text { Chapter } 36\end{array}$ \\
\hline Russia & $\begin{array}{l}\text { Decree of the Government of Russian Federation, } \\
\text { September } 26,2013, \text { No. } 1724-\text { r on the policy of } \\
\text { forest use, protection, and reproduction in the } \\
\text { Russian Federation until } 2030\end{array}$ \\
\hline Canada & $\begin{array}{l}\text { Canadian Wildland Fire Strategy: A Vision for an } \\
\text { Innovative and Integrated Approach to Managing } \\
\text { the Risks and Forest Fires Prevention Act R.S.O. 1990, } \\
\text { Chapter F.24 }\end{array}$ \\
\hline
\end{tabular}

parison is aimed to grasp the most recent insight of forest fire management in Russia, Brazil, Canada, the United States, and Indonesia using six parameters and 19 indicators (Table 2). According to Table 2, forest fire management in Indonesia has fulfilled all components of the disaster management cycle. The research parameters are discussed below.

\subsection{Institution}

In Indonesia, the governmental institutions responsible for forest fire management are the Ministry of Environment and Forestry (KLHK), the National Board of Disaster Mitigation (BNPB), and the Meteorological, Climatological, and Geophysical Agency (BMKG). These institutions play different parts in managing forest fires in Indonesia. The Ministry of Environment and Forestry has the authority before, during, and after a disaster (KLHK c2018). It also oversees environmental law enforcement and publishes relevant regulations. The National Board of Disaster Mitigation is tasked with responding to disasters (BNPB c2017-2020), while the Meteorological, Climatological, and Geophysical Agency monitors the latest conditions of a disaster using satellite and radar technology (BMKG c2020).

The task division for these three different agencies is similar to that of the United States. The United States Forest Service (USFS c2020), Environmental Protection Agency (EPA c2020), and Department of Agriculture (USDA c2020) are responsible for handling forest fire problems in the United States. Similarly, in Russia, the Ministry for Civil Defence, Emergencies and Elimination of Consequences of Natural Disasters (EMERCOM c2020) is assigned the task of managing forest fires, along with the Federal Forestry Agency of Russia (c2020). However, other countries threatened by forest fires, such as Canada and Brazil, have different task divisions. In Canada, only two ministries manage forest fire control, namely the Canadian Council of Forest Ministers (CCFM c2020) and Natural Resources Canada (c2020). As for Brazil, the government has assigned this task to Secretaria Nacional de Dafesa Civil, Ministerio da Integracao Nacional (SEDEC).

Besides governmental institutions, international NonGovernmental Organizations (NGOs) have been focusing their attention on environmental problems in the world, including forest fires. Based on the analysis results, the five countries mentioned above have several NGOs that support the implementation of their forest fire control strategies. For instance, Indonesia has WRI Indonesia (c2020), Center for International Forestry Research (CIFOR), Wahana Lingkungan Hidup Indonesia (WALHI c2020), and WWF Indonesia (c2020). Russia has the International Federation of Red Cross and Red Crescent Societies ([IFRC] International Federation of Red Cross and Red Crescent Societies c2020), WWF Russia (c2020), and Greenpeace Russia (c2020). Furthermore, Canada has the Canadian Interagency Forest Fire Center (CIFFC), while the United States has Forest Trends (c2017-2020), American Forest Foundation (c2017-2020), National Forest Foundation (c2020), and Carbon Canopy (c2020). Meanwhile, in Brazil, Deutsche Gesellschaft für Internationale Zusammenarbeit (2011) is one of the NGOs whose programs are designed to enhance forest fire management, monitor forest fire and deforestation, and protect the Cerrado Forest.

Forest fire control in Indonesia is established in the lowest administrative unit; that is, regency or city under the "Dalkarhutla" organization. Dalkarhutla is the abbreviation of Pengendalian Kebakaran Hutan dan Lahan or Forest 
and Land Fire Control. Russia, specifically EMERCOM, controls forest fire up to the regional level; i.e., the Siberian Regional Center, Southern Regional Center, Central Regional Center, Northwest Regional Center, and a headquarter located in Moscow, named the Moscow Directorate of the Russian Ministry for Emergency Situations. Regional forest fire control is divided into 85 offices built throughout Russia (EMERCOM c2020). Moreover, the Federal Agency for Forestry c.q. the Department of Forestry in seven districts assist in forest fire control in Russia (Federal Forestry Agency of Russia c2020). Meanwhile, in the United States, this task is assigned to the Federal Emergency Management Agency. As for Canada, it has established forest fire control in territorial and provincial agencies. According to the National Civil and Defense Protection Policy Act No 12,608 of 2012, the National System of Civil and Defense Protection in Brazil is not only a federal entity but also a private entity and civil organization.

All five countries employ international cooperation to overcome forest fires. In Indonesia, the National Board of Geospatial Information, the National Board of Disaster Mitigation, the National Board of Land, the Meteorological, Climatological, and Geophysical Agency, the National Aviation and Space Agency, the Ministry of Health, and Dalkarhutla are institutions that cooperate with other organizations worldwide, including ASEAN and UNISDR. Together with Peru, Bolivia, and Argentina, Brazil is incorporated in the International Strategy for Disaster Reduction (ISDR). ISDR is an organization aimed at monitoring Brazil and its neighboring countries (ISDR c2020). Russia, meanwhile, cooperates with several countries in Europe and Asia to stop forest fires. One of the countries in Asia that worked together with Russia during the 2015 forest fire was Indonesia (BBC News Indonesia 2015). Russia also participates actively in international disaster activities through its role as a part- ner in the UNISDR. In the context of forest fires, Canada has been developing partnerships with the United States, Australia, China, New Zealand, Mexico, and Spain (Dubé 1984).

The factors that influence effectiveness of coordinating forest and land fire control include authority, communication, control and leadership (Budiningsih 2017). Strengthening institutional control of forest and land fires requires an institutional structure from the province to the affected site (village). Brigade Forest Fire Control, which is owned by KLHK, has been built at the field level; however, it does not have a structure at the village level, although in several locations a Fire Care Society (MPA) has already been formed, albeit on a voluntary basis. Beside institutions, human resources and budgets for operational costs are also still limited. Coordination of controlling forest and land fire between provinces or regencies is still weak due to lack of supervision, lack of communication, lack of participation, lack of awareness of limited coordination, lack of funding and facilities, and lack of political commitment (Wibowo 2019).

\subsection{Response}

Each of the five countries assessed in this research utilize satellite data to monitor the incidence of forest fires. Indonesia uses NPP, NOAA, and MODIS, while Russia relies on the Russian Space System. The United States uses the products of NOAA and NASA. Meanwhile, Brazil makes use of NOAA and GEOS, and Canada utilizes NOAA and SPOT. The Russian Research Center for Earth Operative Monitoring (NTS OMZ) had a monitoring project of forest fire cases that ran in 2011-2012 (NTS OMZ c2020). The Federal Forestry for Agency in Russia also has a monitoring program called the Fire Alarm Monitoring Unit.

Indonesia has established a firefighter unit for forest fire cases at the regional level. Every region has at least

TABLE 2. Forest fire management and indicators by country.

\begin{tabular}{|c|c|c|c|c|c|c|c|}
\hline Parameters & No. & Indicators & Russian & Brazil & Canada & Indonesia & United States \\
\hline \multirow[t]{4}{*}{ Institution } & 1 & $\begin{array}{l}\text { Existence of forest fire management institution at the } \\
\text { ministerial level }\end{array}$ & $\mathrm{v}$ & $\mathrm{v}$ & $\mathrm{v}$ & $\mathrm{v}$ & $\mathrm{v}$ \\
\hline & 2 & $\begin{array}{l}\text { Existence of non-government organization focusing on } \\
\text { forest fire }\end{array}$ & v & v & $\mathrm{v}$ & v & $\mathrm{v}$ \\
\hline & 3 & $\begin{array}{l}\text { Existence of forest fire monitoring institution at the district } \\
\text { level }\end{array}$ & v & $\mathrm{v}$ & $\mathrm{v}$ & v & v \\
\hline & 4 & International cooperation on forest fire reduction & $\mathrm{v}$ & $\mathrm{v}$ & v & v & $\mathrm{V}$ \\
\hline \multirow[t]{5}{*}{ Response } & 5 & Remote sensing application for forest fire & v & $\mathrm{v}$ & v & $\mathrm{v}$ & $\mathrm{V}$ \\
\hline & 6 & Availability of air force to reduce areas of forest fire & v & $\mathrm{v}$ & v & v & v \\
\hline & 7 & Availability of firefighter units at the district level & v & $\mathrm{v}$ & v & v & V \\
\hline & 8 & Availability of military force to reduce areas of forest fire & v & $\mathrm{v}$ & v & v & $\mathrm{v}$ \\
\hline & 9 & $\begin{array}{l}\text { Availability of health and respiratory equipment during a } \\
\text { forest fire emergency }\end{array}$ & $\mathrm{v}$ & - & $\mathrm{v}$ & $\mathrm{v}$ & $\mathrm{v}$ \\
\hline Reconstruction & 10 & Forest regeneration and restoration & v & $\mathrm{v}$ & v & v & V \\
\hline \multirow[t]{4}{*}{ Prevention } & 11 & Law and regulation on individual penalty for land burning & - & - & v & $\mathrm{v}$ & v \\
\hline & 12 & $\begin{array}{l}\text { Law and regulation on penalty for company/community } \\
\text { involved in land burning }\end{array}$ & - & - & - & v & - \\
\hline & 13 & Law and regulation on land burning & - & - & v & v & V \\
\hline & 14 & $\begin{array}{l}\text { Changes applied to forest fire law and regulation in the last } \\
\text { three years }\end{array}$ & - & - & - & v & $\mathrm{v}$ \\
\hline \multirow[t]{4}{*}{ Mitigation } & 15 & Coping capacity improvement to deal with forest fires & $\mathrm{v}$ & v & v & v & $\mathrm{v}$ \\
\hline & 16 & Early Warning System (EWS) on forest fires & - & - & v & $\mathrm{v}$ & $\mathrm{V}$ \\
\hline & 17 & Existence of disaster prevention center & $\mathrm{v}$ & v & v & v & $\mathrm{v}$ \\
\hline & 18 & Forest management & $\mathrm{v}$ & $\mathrm{v}$ & v & v & V \\
\hline Preparedness & 19 & Availability of disaster response unit at the district level & $\mathrm{v}$ & $\mathrm{v}$ & $\mathrm{v}$ & v & $\mathrm{V}$ \\
\hline
\end{tabular}


one unit of firefighter vehicle and water tank. The other four countries also have firefighter units at the district level. The International Association of Fire Fighters (IAFF) is a firefighter organization in Canada and the United States (IAFF c2020). The fire department under the Russian EMERCOM comprises 220,000 personnel and 18,634 fire engines and special vehicles distributed in 85 offices. The fire department has successfully stopped 450,000 forest fire cases annually and saved up to $35-45$ billion in Russian Rubles (EMERCOM c2020).

Aside from firefighters, military units are often called upon to help with controlling forest fires. In Indonesia, Government Regulation of the Ministry of Environment and Forestry 32/2016, Article 14, authorizes the deployment of military units in assist firefighters in controlling forest fires. The Canadian Armed Forces are also included in a special operation called LENTUS, which handles natural disasters in Canada (Government of Canada 2020). In Russia, EMERCOM has a paramilitary unit to deal with emergencies such as natural disasters (EMERCOM c2020). This paramilitary is a support unit for disaster victims, which distributes supplies during an emergency and builds emergency shelters.

In addition, Brazil, through its National Institute of Meteorology forecasts early warning system together with Pro Arc of Deforestation and Brazilian National Institute for Space Research by monitoring the points with high fire danger rates from remote sensing application which is the Normalized Difference Vegetation Index. Brazil also uses satellite sensor systems for fire detection named Geostationary Operational Environmental Satellite (GOES) and GOES sensors. In combating forest fires, the parties that are in full participation in Brazil are the Military Corp of City Firefighters and Civil Defense Brigades, State centers and superintendence of IBAMA, and voluntary brigades of local communities (Nolasco 2006).

\subsection{Reconstruction}

Forest management systems define how extensive and efficient a country can control forest fires. Indonesia has a regulation for forest management, planning, and utilization. The United States itself passed the National Forest Management Act, while Russia has issued National Policy No. 1724 R that describes forest utilization, protection, and production until 2030 (Government of the Russian Federation 2013), along with the Russian Forest Code (Hitchcock 2011). Inside these documents, the principal, tasks, and management of forest fires in Russia are elaborated. Meanwhile, in Brazil, the Forest Code is mentioned in National Policy No. 12,651. The latest regulation from Indonesia discusses Smart Compensation and Amnesty to reduce illegal logging. Meanwhile, the Canadian regulatory framework for forest management ensures that the Canadian Government is responsible for forest product utilization, protection, and management (Natural Resources Canada 2015).

\subsection{Prevention}

As an effort to prevent forest fires, the Indonesian Government has issued regulations on the punishments for individuals or companies involved in land and forest fires. In accordance with Law No. 32/2009, Article 108, every person who intentionally burns land can be subjected to a minimum fine of IDR 3,000,000,000 and 3 years in jail, or maximum of IDR 10,000,000,000 and 10 years. This Article has the same concept as the law and regulations in the United States, namely, Federal Regulations Title 36 Chapter II Part 261 Subpart A §261.1b, which states that any violation of the prohibitions of the regulation shall be punished by a fine of not more than US\$500 or imprisonment for not more than six months or both pursuant to title 16 U.S.C., section 551. In Canada, the National Policy on Forest Fire Prevention, namely Act R.S.O. 1990, chapter F.24, 35 a and b. It imposes a fine of $\$ 25,000$ or 3-month imprisonment on individuals involved in forest fires and US\$500,000 for individuals associated with a company (Government of Canada 1990).

In Indonesia, land burning for land clearing purposes is permitted under Law No. UU 32/2009 and is further explained in detail in Government Regulation of the Ministry of Environment 32/2016. The same type of permit is also applied in Canada, as stated in the National Policy Act R.S.O 1990, chapter F.24, 35 a and b. In the United States, every person or industry intending to burn a predefined forest area should get permission from the authorized agency. United States has Illinois Pollution Control Board and the Illinois Environmental Protection Agency (Illinois EPA) and DNR Forestry Office of Minnesota for their authorized agency forest fire management (Minnesota Department of Natural Resources c2020; Illinois EPA c2020). On the other hand, Brazil and Russia do not perceive land burning as a punishable act.

The recency of regulation plays a crucial role in forest fire management. In the past several years, Indonesia has changed some of its regulations-in 2016 regarding forest fire control and 2017 regarding national qualification and certification on forest fire management. Meanwhile, the U.S. Forest Service has recently amended the National Forest System Land Management Planning, 36 CFR Part 219. Brazil and Canada have not amended or changed any regulations relevant to forest fire management in the last five years. Based on the recency of their regulations, the Indonesian government has proven to be committed to reducing forest fire disasters.

\subsection{Mitigation}

The Indonesian government has been expressing concerns about the coping capacity of communities. Coping capacity can be upgraded through training, on-the-job training, and formal education (Government of Indonesia 2016). Russia, Canada, and Brazil publicize their upgrading materials on websites and through NGOs, while the United States uses Smokey Bear, a mascot for fire prevention, and Woodsy Owl, a mascot for environmental conservation, to educate people about fire prevention (USDA c2020). The Early Warning System (EWS) in Indonesia is based on online (via websites) and real-time monitoring. For instance, Manggala Agni is an online platform designed to monitor, prevent, and extinguish forest fires. Monitoring tower, CCTV, heat sensor, drone, and aircraft are instruments used to monitor fire incidents in the field. Canada, Brazil, and Russia use website-based EWS. Meanwhile, in the United States, the EWS incorporates satellite images of vegetation developed by researchers at the University of British Columbia (FEMA c2020).

\subsection{Preparedness}

In Indonesia, the Ministry of Environment and Forestry (KLHK) functions as a disaster prevention center. Meanwhile, in Russia, Brazil, and Canada, this function is performed by Forest Fire Center. The United States also has a disaster prevention center, such as the National Center for Disaster Preparedness at Columbia University and the Centers for Disease Control and Prevention in Georgia. Both disaster prevention centers manage not only forest fires 
but also many types of disasters occurring in the United States. Indonesia has KLHK and Damkar for region level also sub-district safety for forest fire response unit for subdistrict level. The same case applies to Russia, Brazil, and Canada. The United States has several disaster response units located in every state, including U.S. National Response Team-an interagency group co-chaired by the EPA and the U.S. Coast Guard-and the Federal Emergency Management Agency (FEMA c2020). Russia has strength in technology and well-integrated institutions responsible for forest fire management. On the other hand, the United States is strong in technology and community capacity. Although forest fire management strategies in Indonesia and Brazil are at the same level, they differ in regulations.

\section{CONCLUSIONS}

Russia, Brazil, Canada, the United States, and Indonesia have differences in forest fire disaster management. All countries have incorporated all components of the disaster management cycle. Indonesia tends to change its regulation change in a short time that the number of forest fire incidents has decreased significantly compared with Russia, Brazil, Canada, and the United States. This situation is believed to have decreased the number of forest fire incidents. Nevertheless, in the context of forest fire management, Indonesia still lacks inter-institutional integration, technological development, and emergency response management.

\section{ACKNOWLEDGMENTS}

We would like to thank the governments of Indonesia, Russia, Brazil, Canada, and the United States for providing the electronic sources of literature on forest fire disaster management that facilitated the purpose of this paper.

\section{AUTHORS' CONTRIBUTIONS}

IAR, AC designed the study. HB, DA, FK, IAR analyzed the data. FK, BKAC wrote the manuscript.

\section{COMPETING INTERESTS}

The authors declare no competing interests.

\section{REFERENCES}

American Forest Foundation. c2017-2020. Washington, DC: American Forest Foundation; [accessed 2018 Mar 15]. ht tps://www.forestfoundation.org.

BBC News Indonesia. 2015 Oct 8. Kabut asap: Presiden minta bantuan empat negara [Haze: the president is asking for help from four countries]. BBC News Indonesia. [accessed 2018 Mar 19]. https://www.bbc.com/in donesia/berita_indonesia/2015/10/151008_indones ia_bantuan_asap.

Beuchelt TD, Virchow D. 2012. Food sovereignty or the human right to adequate food: which concept serves better as international development policy for global hunger and poverty reduction? Agr Hum Values. 29(2):259-273. doi:10.1007/s10460-012-9355-0.

[BMKG] Badan Meteorologi, Klimatologi, dan Geofisika [Meteorology, Climatology, and Geophysical Agency]. c2020. Jakarta: Badan Meteorologi, Klimatologi, dan Geofisika; [accessed 2018 Mar 28]. https://www.bmkg .go.id.
[BNPB] Badan Nasional Penanggulangan Bencana [National Disaster Management Authority]. c2017-2020. Jakarta: Badan Nasional Penanggulangan Bencana; [accessed 2018 Mar 28]. https://bnpb.go.id.

Budiningsih K. 2017. Implementasi kebijakan pengendalian kebakaran hutan dan lahan di Provinsi Sumatera Selatan [Implementation of forest and land fire control policies in South Sumatra province]. Jurnal Analisis Kebijakan Kehutanan. 14(2):165-186. doi:10.20886/jakk.2017 .14.2.165-186.

Carbon Canopy. c2020. Washington, DC: Carbon Canopy; [accessed 2018 Mar 5]. http://www.carboncanopy.c om.

[CCFM] Canadian Council of Forest Ministers. c2020. Ottawa: Canadian Council of Forest Ministers; [accessed 2018 Mar 27]. https://www.ccfm.org/english.

[CIFOR] Center for International Forestry Research. c2020. Bogor: Center for International Forestry Research; [accessed 2018 Mar 22]. https://www.cifor.org.

Deutsche Gesellschaft für Internationale Zusammenarbeit. 2011. Preventing, controlling and monitoring fires in the Cerrado. Bonn and Eschborn: Deutsche Gesellschaft für Internationale Zusammenarbeit. https://www.giz. de/en/worldwide/12505.html.

Dubé DE. 1984. International cooperation in forest fire research. Forest resources management-the influence of policy and law. Proceedings of the International Forest Congress; Ottawa, Canada. p. 401-404.

[EMERCOM] Ministry of the Russian Federation for Civil Defence, Emergencies and Elimination of Consequences of Natural Disasters. c2020. Moscow: Ministry of the Russian Federation for Civil Defence, Emergencies and Elimination of Consequences of Natural Disasters; [accessed 2018 Mar 27]. https://en.mchs.ru.

[FAO] Food and Agriculture Organization. 2015. Global forest resources assessment 2015. Rome: FAO. http: //www.fao.org/forest-resources-assessment/pa st-assessments/fra-2015/en/.

Federal Forestry Agency of Russia. c2020. Moscow: Federal Forestry Agency of Russia; [accessed 2018 Mar 28]. http: //rosleshoz.gov.ru/english.

[FEMA] Federal Emergency Management Agency. c2020. Washington, DC: Federal Emergency Management Agency; [accessed 2018 Mar 30]. https://www.fema .gov.

Forest Trends. c2017-2020. Washington, DC: Forest Trends; [accessed 2018 Mar 11]. https://www.forest-trends.or g.

Gebrehiwot SG, Bewket W, Bishop K. 2014. Community perceptions of forest-water relationships in the Blue Nile Basin of Ethiopia. GeoJournal. 79(5):605-618. doi: 10.1007/s10708-013-9519-5.

Goemans M, Ballamingie P. 2013. Forest as hazard, forest as victim: Community perspectives and disaster mitigation in the aftermath of Kelowna's 2003 wildfires. Can Geogr. 57(1):56-71. doi:10.1111/j.1541-0064.2012.00447.x.

Government of Canada. 1990. Forest fires prevention act, R.S.O. 1990, c. F.24. https://www.ontario.ca/laws/st atute/90f 24 .

Government of Canada. 2020. Operation LENTUS. [accessed 2018 Mar 3]. https://www.canada.ca/en/d epartment-national-defence/services/operations/m ilitary-operations/current-operations/operation-le ntus.html.

Government of Indonesia. 2016. Peraturan Menteri Lingkungan hidup dan kehutanan nomor 44 tahun 2016 
[Minister of Environment and Forestry regulation number 44 of 2016].

Government of the Russian Federation. 2013. State policy on forest use, protection and reproduction in the Russian Federation for the period until 2030. http: //static.government.ru/media/files/9p0rkgpjrP4 euQfWKylV1hHssTtiYOQ6.pdf.

Greenpeace Russia. c2020. Moscow: Greenpeace Russia; [accessed 2018 Mar 14]. http://www.greenpeace.org /russia/en/.

Hirschberger P. 2016. Forests ablaze: causes and effects of global forest fires. Berlin: WWF Deutschland. https: //www.wwf.de/fileadmin/fm-wwf/PublikationenPDF/WWF-Study-Forests-Ablaze.pdf.

Hitchcock E. 2011. The 2006 forest code of the Russian Federation: an evaluation of environmental legislation in Russia. Australian Slavonic and East European Studies. 24(1-2):19-39. https://miskinhill.com.au/journals /a sees /24:1-2/2006-forest-code.

[IAFF] International Association Fire Fighters. c2020. Washington, DC: International Association Fire Fighters; [accessed 2018 Mar 18]. https://www.iaff.org.

[IFRC] International Federation of Red Cross and Red Crescent Societies. c2020. Geneva: International Federation of Red Cross and Red Crescent Societies; [accessed 2018 Mar 14]. https://media.ifrc.org/ifrc.

Illinois [EPA] Environmental Protection Agency. c2020. Open burning permits; [accessed 2018 Mar 23]. https: //www2.illinois.gov/epa/topics/forms/air-permits /Pages/open-burning.aspx.

[ISDR] International Strategy for Disaster Reduction. c2020. Sao Paulo: United Nations Office for Disaster Risk Reduction; [accessed 2018 Mar 15]. https://www.eird.o rg/eng/terminologia-eng.htm.

[KLHK] Kementerian Lingkungan Hidup dan Kehutanan [Ministry of Environment and Forestry of Indonesia]. c2018. Jakarta: Kementerian Lingkungan Hidup dan Kehutanan; [accessed 2018 Mar 29]. https://www.menl hk.go.id.

Minnesota Department of Natural Resources. c2020. Burning permit information; [accessed 2018 Mar 28]. https: //www.dnr.state.mn.us/forestry/fire/questions.ht $\mathrm{ml}$.

National Forest Foundation. c2020. Missoula: National Forest Foundation; [accessed 2018 Mar 1]. https://www. nationalforests.org.

Natural Resources Canada. 2015. Canada's regulatory framework for forest management. Ottawa: Natural Resources Canada. https://cfs.nrcan.gc.ca/pubwareh ouse/pdfs/35982.pdf.

Natural Resources Canada. c2020. Ottawa: Natural Resources Canada; [accessed 2018 Mar 26]. https://ww w.nrcan.gc.ca.

Nolasco MIM. 2006. Global forest resources assessment 2005-report on fires in the South American Region. Rome: FAO. https://gfmc.online/programmes/u n/fao/FAO-Final-12-Regional-Reports-FRA-2005/W P\%20FM05E\%20South\%20America.pdf.

[NTS OMZ] Research Center for Earth Operative Monitoring. c2020. Moscow: Research Center for Earth Operative Monitoring; [accessed 2018 Mar 7]. http://eng.nt somz.ru.
PPI Dunia. 2017 Mar 21. Hutan untuk kehidupan [Forest for life] [blog]. PPI Dunia. [accessed 2018 Mar 21]. http:// old.ppidunia.org/hutan-untuk-kehidupan/.

Pringadi BH. 2004. Pengendalian kerusakan lahan, hutan dan air [Control of damage to land, forests and water]. INFOMATEK. 6(1):47-50.

Rábade JM, Aragoneses C. 2008. Social impact of largescale forest fires. Paper presented at: The Second International Symposium on Fire Economics, Planning, and Policy: A Global View; Córdoba, Spain. p. 23-34.

Riyanto IA, Sholihah RA, Cahyadi A. 2019. Comparative analysis of disaster information website based on web usability evaluation and quality content of disaster information. Paper presented at: ICST 2018. Proceedings of the 4th International Conference on Science and Technology; Yogyakarta, Indonesia. p. 1-7. doi:10.1051/e3sc onf/20197603009.

Salghuna NN, Prasad PC, Kumarib JA. 2018. Assessing the impact of land use and land cover changes on the remnant patches of Kondapalli reserve forest of the Eastern Ghats, Andhra Pradesh, India. Egypt J Remote Sens Space Sci. 21(3):419-429. doi:10.1016/j.ejrs.2018.01.005.

Tacconi L. 2003. Fires in Indonesia: causes, costs and policy implications. Bogor: CIFOR. https://www.cifor.org/ publications/pdf_files/OccPapers/OP-038.pdf.

[UNISDR] United Nations Office for Disaster Risk Reduction. 2017. National disaster risk assessment: governance system, methodologies, and use of results. Geneva: UNISDR. https://www.unisdr.org/files/g lobalplatform/591f213cf2fbe52828_wordsintoaction guideline.nationaldi.pdf.

[US EPA] United States Environmental Protection Agency. c2020. Washington, DC: Environmental Protection Agency; [accessed 2018 Mar 27]. https://www.epa.gov.

[USDA] United States Department of Agriculture. c2020. Washington, DC: Department of Agriculture; [accessed 2018 Mar 27]. https://www.usda.gov.

[USFS] United States Forest Service. c2020. Washington, DC: United States Forest Service; [accessed $2018 \mathrm{Mar}$ 26]. https://www.fs.usda.gov.

[WALHI] Wahana Lingkungan Hidup Indonesia. c2020. Jakarta: Wahana Lingkungan Hidup Indonesia; [accessed 2018 Mar 21]. https://walhi.or.id.

Wibowo KA. 2019. Manajemen penanganan kebakaran hutan dan lahan (Karhutla) guna peningkatan ekonomi kerakyatan. [Management of forest and land fires management (Karhutla) to improve community economy]. Jurnal Studi Sosial dan Politik. 3(1):69-83.

[WRI Indonesia] World Resources Institute Indonesia. c2020. Jakarta: WRI Indonesia; [accessed 2018 Mar 19]. http://www.wri-indonesia.org.

[WRI] World Resources Institute. c2020. Forests: sustaining forests for people and planet. Washington, DC: World Resources Institute; [accessed 2018 Mar 30]. ht tp://www.wri.org/our-work/topics/forests.

WWF Indonesia. c2020. Jakarta: WWF Indonesia; [accessed 2018 Mar 19]. http://www.wwf.id.

WWF Russia. c2020. Moscow: WWF Russia; [accessed 2018 Mar 15]. https://wwf.ru. 